\title{
Improvement in Soil Physical, Chemical and Microbiological Properties during Cropping Cycles under Different Nutrient Managements in Western Himalayas
}

\author{
D.K. Parmar" and D.R. Thakur
}

\author{
CSK Himachal Pradesh Krishi Vishvavidyalaya, Hill Agricultural Research and Extension \\ Centre, Bajaura, India \\ *Corresponding author
}

\section{A B S T R A C T}

\begin{abstract}
Keywords
Carbon

sequestration,

Nutrient

managements,

Cropping cycles,

Western Himalayas.

Article Info

Accepted:

04 May 2017

Available Online:

10 June 2017

It is still unclear that whether organic manure amendment could increase soil organic carbon (SOC) sequestration in an Indian Typic Udorthents. Further, changes accompanied by different organic carbon (C) fractions are not well understood based on long term experiment. The knowledge of this kind is important for assessing the potential for $\mathrm{C}$ sequestration and selecting effective management practices for increasing soil $\mathrm{C}$ sequestration and productivity in agro-ecosystem of western Himalayan region. Thus, we conducted the research based on 9 years (2004 to 2013) of long-term fertilization experiment with three management practices (organic, inorganic and integrated) and four cropping systems [tomato (Solanum lycopersicum L.) -cauliflower (Brassica oleracea var. brotytis) - green pea (Pisum sativum L var. arvense); french bean (Phaselous vulgaris L.) french bean - cauliflower; cauliflower - cauliflower- green pea; Maize (Zea mays L.) + French bean - garlic (Allium sativum L.)]. The results indicate that the soil bulk density in surface depth decreased $\left(1.40 \mathrm{~g} \mathrm{~cm}^{-3}\right)$ but increased $\left(1.42 \mathrm{~g} \mathrm{~cm}^{-3}\right)$ in sub surface. The soil top layer had highest organic carbon $(1.07 \%)$; growth of soil bacteria $\left(8.6106 \mathrm{cfu} \mathrm{g}^{-1}\right)$, fungi (4.5 $\left.106 \mathrm{cfu} \mathrm{g}^{-1}\right)$ and phosphatase enzyme $\left(9.3 \mu \mathrm{p}\right.$-nitrophenol $\left.\mathrm{g}^{-1}\right)$; soil organic carbon stock $\left(22.5\right.$ t.ha $\left.^{-1} \mathrm{yr}^{-1}\right)$; carbon sequestration $\left(17.0\right.$ t.ha $\left.^{-1} \mathrm{yr}^{-1}\right)$; carbon sequestration rate $\left(2.5\right.$ t.ha $\left.^{-1} \mathrm{yr}^{-1}\right) ; \mathrm{C}$ fract1 $\left(0.48\right.$ t.ha $\left.^{-1} \mathrm{yr}^{-1}\right) ; \mathrm{C}$ farct2 $\left(0.25\right.$ t.ha $\left.^{-1} \mathrm{yr}^{-1}\right) ; \mathrm{C}$ fract3 $\left(0.14\right.$ t.ha ${ }^{-1}$ $\left.\mathrm{yr}^{-1}\right) ; \mathrm{C}$ fract4 $\left(0.21 \mathrm{t}^{-h^{-1}} \mathrm{yr}^{-1}\right)$ with organic inputs. The cropping systems had less effect on soil bulk density but other soil variables were significantly influenced in top soil layer, but not in sub layer. The cauliflower - cauliflower - green pea system recorded maximum improvement for organic carbon $(0.88 \%)$; total soil organic carbon stock $\left(18.9 \mathrm{t} \mathrm{ha}^{-1} \mathrm{yr}^{-1}\right)$; carbon sequestration $\left(11.7 \mathrm{tha}^{-1} \mathrm{yr}^{-1}\right)$ and carbon sequestration rate $\left(2.9 \mathrm{t}^{-h^{-1}} \mathrm{yr}^{-1}\right) \mathrm{C}$ fract1 $\left(0.35\right.$ t.ha $\left.^{-1} \mathrm{yr}^{-1}\right), \mathrm{C}$ farct2 $\left(0.22\right.$ t.ha $\left.^{-1} \mathrm{yr}^{-1}\right) ; \mathrm{C}$ fract3 $\left(0.12\right.$ t.ha $\left.^{-1} \mathrm{yr}^{-1}\right) ; \mathrm{C}$ fract4 $\left(0.17\right.$ t.ha ${ }^{-1}$ $\left.\mathrm{yr}^{-1}\right)$; bacteria $\left(8.7106 \mathrm{cfu} \mathrm{g}^{-1}\right)$; fungi (3.2 $\left.106 \mathrm{cfu} \mathrm{g}^{-1}\right)$ and phosphatase enzyme (7.6 $\mu \mathrm{p}$ nitrophenol $\mathrm{g}^{-1}$ ). The results indicate that the Typic Udorthents have a large potential to sequester SOC and applying cattle manure or vermicompost is a recommendable SOC sequestration practice in western Himalayan regions.
\end{abstract}

\section{Introduction}

There is a growing concern that increasing levels of carbon dioxide in the atmosphere will change the climate, making the Earth warmer and increasing the frequency of extreme weather events (Sundermeier et al., 2005). Over the past 150 years, the amount of carbon in the atmosphere has increased by $30 \%$ (Ecological Society of America). One of 
the proposed methods to reduce atmospheric carbon dioxide is to increase the global storage of carbon in soils which can eventually result to simultaneous enhancement in agricultural production (Ecological Society of America). Organic matter in soils acts as a large carbon sink and plays an important role in the $\mathrm{CO}_{2}$ balance (Sukkel et al., 2008). However, there is little information on how different nutrient management strategies could influence soil carbon sequestration in the long term during cropping cycles. Earlier studies considered soil carbon sequestration in the short term and mostly in tropical climates. This study was specifically conducted in a sub- tropical climate to evaluate soil carbon sequestration potential under different nutrient management strategies. In an era when global warming is increasingly becoming an environmental threat to human existence, there is a need for studies of this nature which can provide information on the best soil amendments and cropping systems which will enhance soil carbon sequestration in the long term with increased crop yield/productivity. Also an understanding of the dynamics of carbon (C) stock in soils, as impacted by management strategies, is necessary to identify the pathways of $\mathrm{C}$ sequestration in soils and for maintaining soil organic $\mathrm{C}$ (SOC) at a level critical for up keeping soil health and also for restraining global warming (Bastia et al., 2013, Bonilla et al., 2012). Therefore, fractionating and quantifying the labile and recalcitrant $\mathrm{C}$ pools could provide valuable information for better understanding SOC changes and the underlying mechanisms (Behera et al., 2007). Long-term fertilizer experiments showed that applying chemical fertilizer in combination with farmyard manure significantly increased SOC content more than using chemical fertilizer alone in tropical cropping system (Lima et al., 2009) and semi-arid tropics (Banger et al., 2009). The responses of various SOC fractions to increased organic manure and carbon stock and carbon sequestration potential are not well documented in the Typic Udorthents based on long-term experiments. The present study aimed with the hypothesis that continuous manure application under a yearround vegetable production system would store more $\mathrm{C}$ in soil and reduce emission of $\mathrm{CO}_{2}$ and would have the potential to adapt and mitigate the climate change impacts in the western Himalayan regions.

\section{Materials and Methods}

\section{Site description}

The experiment is located at the experimental farm of Himachal Pradesh Krishi Vishvavidayalaya, Hill Agricultural Research and Extension Centre, Bajaura, Kullu, India $\left(31.8^{\circ} \mathrm{N}\right.$ latitude, $77^{\circ} \mathrm{E}$ longitude). The climate is sub- humid and sub-tropical, receives annual rainfall of 1500-3000 $\mathrm{mm}$. Before initiating the field trial, the soil was silty clay loam and soil $\mathrm{pH}$ at top layer $(0-0.15 \mathrm{~m})$ and sub surface $(0.15-0.3 \mathrm{~m})$ was 6.5 and 6.4 (1:2.5 soil: water suspension), bulk density $1.36 \mathrm{~g} \mathrm{~cm}^{-3}$ and easily oxidizable $\left(\mathrm{K}_{2} \mathrm{Cr}_{2} \mathrm{O}_{7}+\right.$

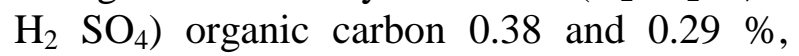
respectively.

\section{Experimental design}

The long-term field experiment was initiated in 2004. The experiment consisted of three management practices $[100 \%$ organic (recommended dose of NPK fertilizer supplemented through a mix of farmyard manure and vermicompost); 100\% inorganic (recommended NPK fertilizer); integrated (50\% of recommended NPK fertilizer $+50 \%$ NPK supplemented through a mix of farmyard manure and vermicompost] and four cropping systems [tomato (Solanum lycopersicum L. var. commune) -cauliflower (Brassica oleracea var. brotytis)- green pea (Pisum sativum L.var. arvense); frenchbean 
(Phaselous vulgaris L.) - frenchbeancauliflower; cauliflower - cauliflower- green pea; maize (Zea mays L.) + frenchbean garlic (Allium sativum var. sativum] with permanent fixed plot size. The net plot size was $50 \mathrm{~m}^{2}(10 \mathrm{~m} \times 5 \mathrm{~m})$. Each strip was isolated by $1 \mathrm{~m}$ deep plates. Mineral N, P and $\mathrm{K}$ fertilization was urea, single superphosphate and muriate of potash, respectively. The mean chemical characteristics of farmyard manure were $2.35 \% \mathrm{~N}, 0.27 \% \mathrm{P}, 2.39 \% \mathrm{~K}$ and that of vermicompost was $68 \% \mathrm{~N}, 0.20 \% \mathrm{P}, 1.28 \%$ $\mathrm{K}$. The farmyard and vermicompost used in the trial were applied on the nitrogen equivalent basis as per nutrient requirement of each crop. Phosphorus requirement of the crops were met through rock phosphate (32\% P) in organic treatment. The transplanting of tomato, cauliflower and sowing of pea, maize, frenchbean and garlic was done as per the state level recommended package of practices. The organic manures according to the treatment were applied to organic and integrated nutrient management plot two weeks before sowing. The mineral fertilizers in inorganic and integrated (recommended $\mathrm{N}$ : P: K dose of 20:60:30 kg ha ${ }^{-1}$ for garden pea, french bean, 125:75:55 kg ha-1 for tomato and cauliflower, 100:60:50 kg ha ${ }^{-1}$ for garlic and 90:60:45 for maize) were applied in two equal splits (half dose at the sowing/transplanting time and remaining half dose 30-45 days after transplanting/sowing). No chemical insecticides and pesticides were used in organic nutrient management strip, however, integrated pest management (IPM) and integrated disease management (IDM) in integrated nutrient management and inorganic treatment were taken up for insect and disease control.

\section{Soil sampling and analysis}

Triplicate soil samples at two soil depths (0$0.15,0.15-0.3 \mathrm{~m})$ from each strip were collected at the initiation of trial (2004) and after 9th cropping cycle (2013-14). The samples were air-dried, ground and passed through a $0.2-\mathrm{mm}$ sieve and stored at room temperature.

\section{Estimation of soil properties}

Soil bulk density (BD, Mg. $\mathrm{m}^{-3}$ ) was determined using a core sampler (diameter 7 $\mathrm{cm}$ and height $8 \mathrm{~cm}$ ). Soil organic carbon was estimated with method of Walkley and Black (1934).

The enumeration of total bacteria and fungi was carried out by serial dilution plate count technique using nutrient agar for bacteria and Martin's Rose Bengal agar for fungi (Martin, 1950). Acid phosphatase activity was measured by the method of (Arutyunyan and Galstyan, 2003).

\section{Estimation of carbon stock, carbon} sequestration and potential

The soil carbon stock was computed by the formula given by (Joao Carlos 2001):

SOC $\mathrm{t} \mathrm{ha}^{-1}=$ bulk density $\left(\mathrm{mg} \mathrm{m}^{-3}\right) \times$ organic carbon $(\%) \times$ soil depth $(\mathrm{cm})$

The carbon sequestration in soil was calculated as follow:

Carbon sequestration $\left(\mathrm{t} \mathrm{Cha}^{-1} \mathrm{yr}^{-1}\right)=\mathrm{OC}_{\text {current }}$ $\mathrm{OC}_{\text {initial }}$

where, $\mathrm{OC}_{\text {current }}$ and $\mathrm{OC}_{\text {initial }}$ indicate the organic carbon stocks in 2013 (current) and that at the initiation of the long-term experiment in 2004, respectively.

Carbon sequestration rate was computed using the formula:

SOC stock / No. of years of experimentation 


\section{Estimation of carbon pools}

Organic C fractions were determined by wet oxidation using the method proposed by (Chan et al., 2001). One half gram of ground $(0.5 \mathrm{~mm})$ soil was placed in a $500 \mathrm{ml}$ Erlenmeyer flask to which $10 \mathrm{ml} 0.167 \mathrm{~mol} / \mathrm{L}$ $\mathrm{K}_{2} \mathrm{Cr}_{2} \mathrm{O}_{7}$ was first added, followed by 5 and $10 \mathrm{ml}$ of concentrated sulphuric acid instead of the $20 \mathrm{ml}$ specified by Walkley and Black (1934). Oxidation was carried out with an external heat source (average temperature of $140^{\circ} \mathrm{C}$ ) and the extract obtained was dissolved with $80 \mathrm{ml}$ distilled water. The excess dichromate was determined by titrating against $0.5 \mathrm{~mol} / \mathrm{L} \mathrm{Fe}\left(\mathrm{NH}_{4}\right)_{2}\left(\mathrm{SO}_{4}\right)_{2} \cdot \mathrm{H}_{2} \mathrm{O}$. The resulting three acid-aqueous solution ratios of $0.5: 1, \quad 1: 1$, and 2:1 (which corresponded respectively to 6,9 and $12 \mathrm{~mol} / \mathrm{L} \mathrm{H}_{2} \mathrm{SO}_{4}$ ) allowed comparison of oxidizable organic carbon extracted under increasing oxidizing conditions. The amount of oxidizable organic carbon determined using 5, 10, and $20 \mathrm{ml}$ of concentrated sulphuric acid when compared with total carbon concentration allowed separation of total organic carbon into four fractions of decreasing oxidizability (Chan $e t$ al., 2001):

Fraction 1: organic carbon oxidizible under 6 $\mathrm{mol} \mathrm{l}^{-1} \mathrm{H}_{2} \mathrm{SO}_{4}$ and corresponds

to the labile fraction of organic $\mathrm{C}$;

fraction 2: the difference in oxidizible organic carbon extracted between 9 and

$6 \mathrm{~mol} \mathrm{l}^{-1} \mathrm{H}_{2} \mathrm{SO}_{4}$ and corresponds to the moderately labile fraction;

Fraction 3: the difference in oxidizible organic carbon extracted between 12 and 9 mol ${ }^{-1} \mathrm{H}_{2} \mathrm{SO}_{4}$ and corresponds to the slightly labile fraction. The $12 \mathrm{~mol} \mathrm{l}^{-1} \mathrm{H}_{2} \mathrm{SO}_{4}$ is equivalent to the standard Walkley and Black method; and

fraction 4: residual organic carbon after reaction with $12 \mathrm{~mol}^{-1} \mathrm{H}_{2} \mathrm{SO}_{4}$ and corresponds to the recalcitrant fraction of organic C.

\section{Data analysis}

All the data was arranged in a strip plot design keeping cropping system in main plot and nutrient management practice in sub-plot. Statistical analyses were performed using CPCS1 software package. Significant differences were analyzed using LSD test at significance level $\mathrm{P}=0.05$.

\section{Results and Discussion}

\section{Soil properties}

Soil organic carbon and bulk density recorded significant change at two depths due to nutrient management practices (Table 1) but cropping systems had no effect on soil bulk density. The largest increase for soil organic carbon $(1.07 \%)$ was recorded under organic practice at top layer and decreased at sub surface depth $(0.90 \%)$. On the other hand, organic practice tended to decrease soil bulk density in surface depth $\left(1.40 \mathrm{mg} \mathrm{m}^{-3}\right)$ but increased in sub surface depth $\left(1.42 \mathrm{mg} . \mathrm{m}^{-3}\right)$, which suggests that long-term application of organic amendments significantly improved soil physical conditions (Table 1).

The soil microbial properties due to management practices increased in surface depth and observe decreasing trend with increased soil depth (Table 2). The organic practice in comparison to inorganic and integrated practice recorded higher growth of bacteria ( 8.6 and $4.8106 \mathrm{cfu} \mathrm{g}^{-1}$ ), fungi (4.5 and $1.6106 \mathrm{cfu} \mathrm{g}^{-1}$ ) and phosphatase enzyme (9.3 and $3.9 \mu$ p-nitrophenol $\mathrm{g}^{-1}$ ) in top layer than sub surface depth. The cropping systems exhibited a significant effect on soil microbial properties in top soil layer, however no effect was observed in sub layer. The highest count in top layer with respect to bacteria (8.7 106 
cfu $\mathrm{g}^{-1}$ ), fungi (3.2 $106 \mathrm{cfu} \mathrm{g}^{-1}$ ) phosphatase enzyme (7.6 $\mu \mathrm{p}$-nitrophenol $\left.\mathrm{g}^{-1}\right)$ was recorded in cauliflower - cauliflower - green pea system as compared to other cropping systems (Table 2).

Our results clearly show that trends in soil properties depend on long-term fertilization regime. Significant changes observed in soil properties over time for organic treatment are consistent with the observations reported by Purakayastha et al., (2008), which attributed improvement in soil bulk density in organic manure incorporated soils to the build-up of soil organic matter and better soil structure. This also agrees with the findings of Bastia et al., (2013) and Lima et al., (2009) where improved soil bulk density was observed due to incorporation of organic manure into the soil. Ma et al., (2011) also attributed the improvement in bulk density of soil treated with organic manures, mainly due to the enhanced microbial population and activity that resulted in the formation of aggregates and increased porosity.

Among tested fertilizer treatments, organic fertilizer had significant impact on soil microbial properties. The maximum microbial growth in organic treated plots was due to the presence of easily water soluble $\mathrm{C}$ and $\mathrm{N}$ in FYM (Paul et al., 2003), which acts as a source of energy for soil organisms, whereas the easily soluble $\mathrm{C}$ component was missing in mineral fertilizer (Behera et al., 2007) and, hence, the microbial population was less in the plots under NPK. The current findings are in the agreement with results obtained by (Bonilla et al., 2012, Zhang et al., 2012). The effect of organic amendments on enzyme activities was probably a combined effect of a higher degree of enzymes stabilization to humic substances and an increase in microbial biomass with increased soil carbon concentration (Garcia et al., 2008), (Liu et al., 2013, Mohammadi et al., 2011). Agricultural practices such as crop rotation along with inclusion of legumes in rotations, increases carbon biomass resulting higher population of micro flora in soil (Venkatesh et al., 2013).

\section{Carbon stocks and carbon sequestration}

Table 3 revealed that organic practice had higher carbon storage $\left(22.5 \mathrm{tha}^{-1} \mathrm{yr}^{-1}\right)$, carbon sequestration (17.0 t.ha $\mathrm{yr}^{-1}$ ) and carbon sequestration rate $\left(2.5 \mathrm{t} \mathrm{ha}^{-1} \mathrm{yr}^{-1}\right)$ in top layer than sub surface layer. The maximum value for organic carbon $(0.88 \%)$, total soil organic carbon stock (18.9 t. ha $\left.^{-1} \mathrm{yr}^{-1}\right)$, carbon sequestration (11.7 t.ha $\mathrm{yr}^{-1}$ ) and carbon sequestration rate $\left(2.9\right.$ t.ha $\left.^{-1} \mathrm{yr}^{-1}\right)$ in top layer was recorded in cauliflower - cauliflower pea system (Table 3).

The present study revealed that value of carbon sequestration and dynamics was maximum in top layer as compared to subsurface depth. The decrease in the soil organic carbon stock, carbon potential and rate with the depth may be due to relatively low microbial population in the subsurface layers and decreased decomposition activity (Sukkel et al., 2008). According to (Shrestha et al., 2008), the surface layer in agricultural soil also have more carbon than subsurface layer because the surface layer remains in dynamic equilibrium with biological and anthropological activities and thus is generally richer in carbon than the subsurface layers. The abundance of litter available for decomposition in the surface layer makes the release of the labile compounds in the surface layer thus making it rich in terms of soil organic carbon (Sukkel et al., 2008). According to (Kundu et al., 2007), crop rotation is among the best management practices for increasing soil carbon stock. Similar results were obtained in the study done by (Gaiser et al., 2009, Abreu et al., 2011) in which SOC content in soil was increased due to different crop rotations. 
Table.1 Soil organic carbon and bulk density of cropping systems under

Different management practices

\begin{tabular}{|c|c|c|c|c|}
\hline \multirow[t]{3}{*}{ Treatment } & \multicolumn{2}{|c|}{$\mathrm{OC}(\%)$} & \multicolumn{2}{|c|}{ BD $\left(\mathrm{Mg} . \mathrm{cm}^{-3}\right)$} \\
\hline & \multicolumn{2}{|l|}{ Depth (m) } & & \\
\hline & $0-0.15$ & $0.15-0.3$ & $0-0.15$ & $0.15-0.3$ \\
\hline Management Practice & & & & \\
\hline Organic & 1.07 & 0.90 & 1.40 & 1.42 \\
\hline Inorganic & 0.71 & 0.48 & 1.46 & 1.50 \\
\hline Integrated & 0.84 & 0.69 & 1.42 & 1.45 \\
\hline $\mathrm{CD} p=0.05$ & 0.04 & 0.04 & 0.01 & 0.02 \\
\hline Cropping system & & & & \\
\hline $\begin{array}{l}\text { Tomato-cauliflower- } \\
\text { pea }\end{array}$ & 0.86 & 0.68 & 1.40 & 1.46 \\
\hline $\begin{array}{l}\text { Frenchbean- } \\
\text { frenchbean- } \\
\text { cauliflower }\end{array}$ & 0.80 & 0.68 & 1.41 & 1.46 \\
\hline $\begin{array}{l}\text { Cauliflower- } \\
\text { cauliflower-pea }\end{array}$ & 0.88 & 0.69 & 1.40 & 1.45 \\
\hline $\begin{array}{l}\text { Maize +frenchbean- } \\
\text { Garlic }\end{array}$ & 0.84 & 0.70 & 1.40 & 1.45 \\
\hline $\mathrm{CD} \mathrm{p}=0.05$ & 0.1 & NS & NS & NS \\
\hline
\end{tabular}

Table.2 Soil microbial properties of cropping systems under different management practices

\begin{tabular}{|c|c|c|c|c|c|c|}
\hline \multirow[t]{2}{*}{ Treatment } & \multicolumn{2}{|c|}{$\begin{array}{c}\text { Bacteria } \\
\left(10^{6} \mathrm{cfu} \mathrm{g}^{-1}\right)\end{array}$} & \multirow{2}{*}{\multicolumn{2}{|c|}{$\begin{array}{c}\begin{array}{c}\text { Fungi } \\
\left(10^{5} \mathrm{cfu} \mathrm{g}^{-1}\right)\end{array} \\
\text { Depth }(\mathrm{m})\end{array}$}} & \multicolumn{2}{|c|}{$\begin{array}{l}\text { Phosphatase enzyme } \\
\left(\mu \text { p-nitrophenol } g^{-1}\right)\end{array}$} \\
\hline & & & & & & \\
\hline Management Practice & $0-0.15$ & $0.15-0.30$ & $0-0.15$ & $0.15-0.30$ & $0-0.15$ & $0.15-0.30$ \\
\hline Organic & 8.6 & 4.8 & 4.5 & 1.6 & 9.3 & 3.9 \\
\hline Inorganic & 7.7 & 1.5 & 0.9 & 0.4 & 3.7 & 1.6 \\
\hline Integrated & 8.2 & 4.2 & 4.2 & 1.3 & 8.7 & 3.5 \\
\hline $\mathrm{CD} p=0.05$ & 0.01 & 0.13 & 0.07 & 0.04 & 0.17 & 0.08 \\
\hline Cropping system & & & & & & \\
\hline Tomato-cauliflower-pea & 8.0 & 3.7 & 3.2 & 1.2 & 7.4 & 2.8 \\
\hline $\begin{array}{l}\text { Frenchbean-frenchbean- } \\
\text { cauliflower }\end{array}$ & 7.0 & 3.7 & 3.1 & 1.0 & 7.0 & 2.9 \\
\hline $\begin{array}{l}\text { Cauliflower- } \\
\text { cauliflower-pea }\end{array}$ & 8.7 & 3.8 & 3.8 & 1.4 & 7.6 & 2.8 \\
\hline $\begin{array}{l}\text { Maize +frenchbean- } \\
\text { Garlic }\end{array}$ & 7.0 & 3.7 & 3.2 & 1.3 & 7.2 & 2.7 \\
\hline $\mathrm{CD} p=0.05$ & 0.01 & NS & 0.08 & NS & 0.14 & NS \\
\hline
\end{tabular}


Table.3 Soil carbon storage and sequestration of cropping systems under Different management practices

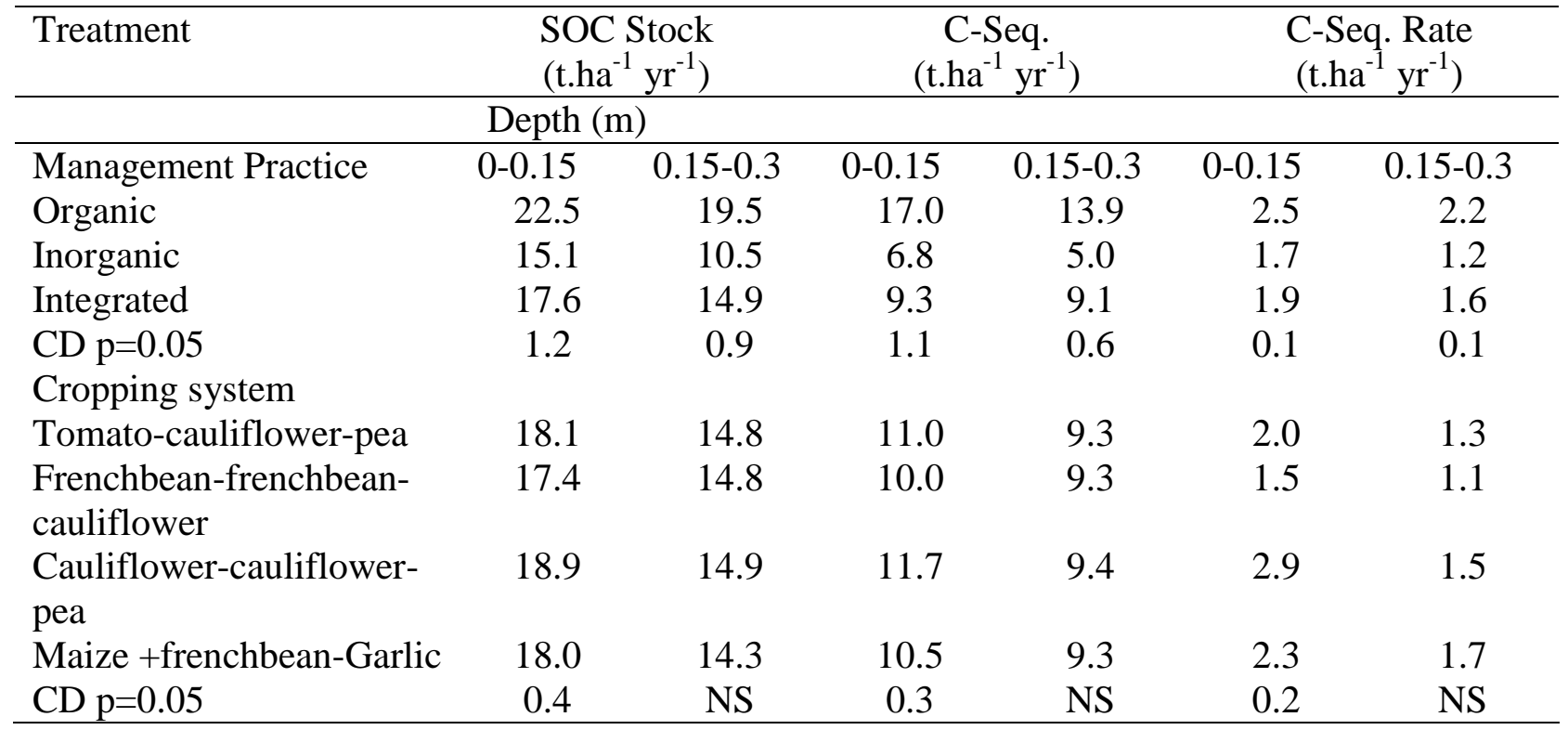

Table.4 Soil organic fractions of cropping systems under different management practices

\begin{tabular}{|c|c|c|c|c|c|c|c|c|}
\hline \multirow[t]{3}{*}{ Treatment } & \multicolumn{8}{|c|}{ Carbon Fraction } \\
\hline & \multicolumn{2}{|c|}{$\mathrm{C}$ fraction $_{1}$} & \multicolumn{2}{|c|}{$\mathrm{C}$ fraction $_{2}$} & \multicolumn{2}{|c|}{$\mathrm{C}$ fraction $_{3}$} & \multicolumn{2}{|c|}{$\mathrm{C}$ fraction $_{4}$} \\
\hline & \multicolumn{8}{|c|}{ Depth $(\mathrm{m})$} \\
\hline Management Practice & $0-0.15$ & $\begin{array}{l}0.15- \\
0.3\end{array}$ & $\begin{array}{c}0- \\
0.15\end{array}$ & $\begin{array}{c}0.15- \\
0.3\end{array}$ & $\begin{array}{c}0- \\
0.15\end{array}$ & $\begin{array}{l}0.15- \\
0.3\end{array}$ & $\begin{array}{c}0- \\
0.15\end{array}$ & $\begin{array}{c}0.15- \\
0.3\end{array}$ \\
\hline Organic & 0.48 & 0.33 & 0.25 & 0.21 & 0.14 & 0.10 & 0.21 & 0.19 \\
\hline Inorganic & 0.24 & 0.24 & 0.20 & 0.17 & 0.10 & 0.07 & 0.16 & 0.11 \\
\hline Integrated & 0.30 & 0.24 & 0.21 & 0.19 & 0.12 & 0.09 & 0.18 & 0.15 \\
\hline $\mathrm{CD} \mathrm{p}=0.05$ & 0.028 & 0.030 & 0.017 & 0.019 & 0.007 & 0.01 & 0.012 & 0.014 \\
\hline Cropping system & & & & & & & & \\
\hline Tomato-cauliflower-pea & 0.32 & 0.27 & 0.21 & 0.21 & 0.11 & 0.13 & 0.16 & 0.17 \\
\hline $\begin{array}{l}\text { Frenchbean-frenchbean- } \\
\text { cauliflower }\end{array}$ & 0.32 & 0.26 & 0.20 & 0.21 & 0.11 & 0.11 & 0.15 & 0.15 \\
\hline $\begin{array}{l}\text { Cauliflower-cauliflower- } \\
\text { pea }\end{array}$ & 0.35 & 0.28 & 0.23 & 0.20 & 0.13 & 0.12 & 0.17 & 0.17 \\
\hline Maize +frenchbean-Garlic & 0.33 & 0.26 & 0.21 & 0.20 & 0.10 & 0.12 & 0.15 & 0.16 \\
\hline $\mathrm{CD} p=0.05$ & 0.016 & NS & 0.011 & NS & 0.010 & NS & 0.017 & NS \\
\hline
\end{tabular}

Agricultural system has shown better results under crop rotations practices as many studies have shown in the past (Kaur et al., 2008). The total carbon stock in agricultural system also included crop residue input into the soil and in this way it enhanced total carbon stock in agricultural system. According to Shah et $a l$. , (2003) the change in soil carbon stock is directly related to $\mathrm{C}$ input from crop residues and organic amendments. Enhanced C 
sequestration in agricultural soils not only has the potential to help reduce atmospheric $\mathrm{CO}_{2}$ concentrations, but also promotes the productivity and sustainability of agricultural systems (Kundu et al., 2007).

\section{Carbon fractions}

The nutrient management practices had a significant effect on the distribution of different carbon pools at the surface and subsurface depth (Table 4). The organic treatment over integrated and inorganic treatment significantly increased $\mathrm{C}$ fraction 1

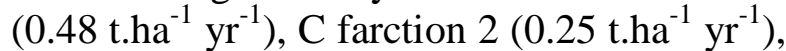
$\mathrm{C}$ fraction 3 (0.14 t.ha $\left.\mathrm{yr}^{-1}\right)$ and $\mathrm{C}$ fraction4 $\left(0.21 .^{-1} \mathrm{yr}^{-1}\right)$ in top soil layer compared with low value recorded for $\mathrm{C}$ fraction 1 ( $0.33 \mathrm{t}^{\mathrm{h}} \mathrm{ha}^{-1}$ $\left.\mathrm{yr}^{-1}\right), \mathrm{C}$ farction $2\left(0.21 \mathrm{t}^{-h^{-1}} \mathrm{yr}^{-1}\right), \mathrm{C}$ fraction 3 (0.10 t.ha ${ }^{-1} \mathrm{yr}^{-1}$ ) and C fraction 4 (0.19 t.ha ${ }^{-1}$ $\left.\mathrm{yr}^{-1}\right)$ in sub surface.

Different C fractions in surface depth recorded significant variation due to variable crop rotation but no effect was observed in sub surface depth (Table 4). Irrespective of cropping system and nutrient management, content of $\mathrm{C}$ fraction 1 at $0-0.15$ and 0.15 $0.30 \mathrm{~m}$ was more than other carbon fractions. The highest $\mathrm{C}$ fraction $1\left(0.35 \mathrm{t}^{-h^{-1}} \mathrm{yr}^{-1}\right), \mathrm{C}$ farction $2\left(0.22 \mathrm{t}^{-h^{-1}} \mathrm{yr}^{-1}\right), \mathrm{C}$ fraction $3(0.12$ t.ha $\left.{ }^{-1} \mathrm{yr}^{-1}\right)$ and $\mathrm{C}$ fraction 4 (0.17 t.ha $\left.{ }^{-1} \mathrm{yr}^{-1}\right)$ was recorded in top soil layer under cauliflower - cauliflower - green pea system of cropping when compared with other systems. SOC fractions with different stabilities and turnover rates are important variables to detect the influence of agricultural management on soil quality. The carbon fractions have been defined as a labile SOC pool mainly consisting of plant residues partially decomposed and not associated with soil minerals. From 2004 to 2013, SOC concentrations $(0-0.15 \mathrm{~m}$ layer $)$ increased significantly for all treatments and the greatest increases occurred for treatment that received organic materials. Apparently, application of only fertilizers did not increase SOC content over long-term cropping. This observation was consistent with that of Rudrappa et al., (2005), Gong et al., (2009), Li et al., (2010) who recorded increase in carbon fractions under organic treatment which was attributed to the availability of additional mineralisable and readily hydrolysable carbon resulting in higher microbial activity (Chan et al., 2001). The inclusion of legumes in cropping systems had beneficial effect on carbon distribution of different soil carbon pools. Higher amounts of carbon fraction under the vegetable cropping systems with legume crops as compared non legume system could be attributed to the addition of more below ground biomass in the form of roots (Ganeshamurthy et al., 2009). Similar increases in soil $\mathrm{C}$ fraction due to inclusion of pulses in cropping system were also reported in long-term experiments (Rudrappa et al., 2005).

This study concluded that organic management of cauliflower-cauliflower-green pea cropping system has ability to accumulate higher amount of soil organic to enhance carbon sequestration and is considered to be the best crop management practice in terms of maintenance of soil environment the western Himalayas.

\section{Acknowledgement}

We thank the ICAR-IIFSR, Modipuram and Meerut, India for providing financial help to initiate research work under Network Project on Organic Farming. We are also greatly grateful for one and all for their direct and indirect help for preparation of this manuscript.

\section{References}

Abreu, S.L., Godsey, C.B., Edwards, J.T., Warren, J.G. 2011. Assessing carbon and 
nitrogen stocks of no-till systems in Oklahoma. Soil and Tillage Research, 117:28-33.

Arutyunyan, E.A. and Galstyan, S.H. 2003. Determination of the activity of alkaline and acid Phosphatase in soils. Agrochimija, 5: 128 - 133.

Banger, K., Kukal, S.S., Toor, G., Sudhir, K., Hanumanthraju, T.H. 2009. Impact of long-term Additions of chemical fertilizers and farm yard manure on carbon and nitrogen sequestration under rice-cowpea cropping system in semi-arid tropics. Plant Soil, 318: 27-35.

Bastia, D.K., Tripathi, S., Barik, T., Kar, C.S., Raha, S., Tripathi, A. 2013. Yield and soil organic carbon sequestration under organic nutrient management in rice-rice system. Journal of Crop and Weed, 9: 5255.

Behera, U.K., Sharma, A.R., Pandey, H.N. 2007. Sustaining productivity of wheatsoybean cropping system through integrated nutrient management practices on the Vertisols of Central India. Plant Soil, 297: 185-199.

Bonilla, N., Cazorla, F.M., Martínez-Alonso M., Hermoso, J.M., González-Fernández, J.J.,

Gaju, N., Landa, B.B., Vicent, A. 2012. Organic amendments and land management affect bacterial community composition, diversity and biomass in avocado crop soils. Plant Soil, 357:215226.

Chan, K.Y., Bowman, A., Oates, A. 2001. Oxidizable organic carbon fractions and soil quality changes in an oxic paleustaff under different pastures leys. Soil Science, 166: 61-67.

Ecological Society of America (ESA). Carbon sequestration in soils, pp. 1- 4.

Ganeshamurthy, A.N. 2009. Soil changes following long-term cultivation of pulses. J. Agric. Science, 147: 699-706.

Gaiser, T., Abdel-Razeka,M., Bakarabet, H. 2009. Modeling carbon sequestration under zero-tillage at the regional scale. II. The influence of crop rotation and soil type. $\quad$ Ecol. $\quad$ Model. doi:10.1016/j.ecolmodel.

Garcia-Ruiz R., Ochoa, V., Hinojosa, M.B., Carreira, J.A. 2008. Suitability of enzymatic activities for the monitoring of soil quality improvement in organic agricultural systems. Soil Biology and Biochemistry, 40:2137-2145.

Gong, W., Yan, X.Y., Wang, J.Y., Hu, T.X., Gong, Y.2009. Long-term manuring and fertilization effects on soil organic carbon pools under a wheat-maize cropping system in North China Plain. Plant Soil, 314: 67-69.

Joao Carlos., Sa de, Carlos,M., Cerri, C., Warren, A.D., Lal, R., Solismar, V. F., Marisa, P., Feigl Brigitte E. 2001. Organic matter dynamics and carbon sequestration rates for a tillage chronosequence in a Brazillian Oxisol. Soil Sci. Soc. Amer. J., 65: 1486-1499.

Kaur, T., Brar, B.S., Dhillon, N.S. 2008. Soil organic matter dynamics as affected by long-term use of organic and inorganic fertilizers under maize_wheat cropping system. Nutr. Cycl. Agroecosys, 81: 5969.

Kundu, S.R., Bhattacharyya, V., Prakash,B., Ghosh, N., Gupta, H.S. 2007. Carbon sequestration and relationship between carbon addition and storage under rainfed soybean-wheat rotation in a sandy loam soil of the Indian. Soil and Tillage Research, 92:87-95.

Lima, D, L, D., Santos, S.M., Scherer, H.W., Schneider, R.J., Duarte, A.C., Santos, E.B.H., Esteves, V, I. 2009. Effects of organic and inorganic amendments on soil organic matter properties. Geoderma, 150: 38-45.

Li, Z.P., Liu, M., Wu, X.C., Han, F.X., Zhang, T.L. 2010. Effects of long-term chemical fertilization and organic amendments on dynamics of soil organic $\mathrm{C}$ and total $\mathrm{N}$ in paddy soil derived from barren land in subtropical China. Soil Till. Res., 106: 268-274.

Liu, Y.R., Li, X., Shen, Q.R., Xu, Y.C. 2013. Enzyme activity in water-stable soil 
aggre- gates as affected by long -term application of organic manure and chemical fertiliser. Pedosphere, 23:111119.

Ma, L., Yang, L.Z., Xia, L.Z., Shen, M.X., Yin, S.X., Li, Y.D. 2011. Long-term effects of inorganic and organic amendments on organic carbon in a paddy soil of the Taihu Lake Region, China. Pedosphere, 21: 186-196.

Martin, J.P. 1950. Use of acid rose-bengal and streptomycin in plate method for estimating soil fungi. Soil Science, 69: 215-232.

Mohammadi, K., Ghalavand, A., Aghaalikhani, M., Heidari, G., Shahmoradi, B., Sohrabi, Y. 2011. Effect of different methods of crop rotation and fertilization on canola traits and soil microbial activity. Australian Journal of Crop Science, 5(10): 1261-1268.

Paul, E.A., Morris, S.J., Six, J., Paustian, K., Gregorich, E.G. 2003. Interpretation of soil carbon and nitrogen dynamics in agricultural and afforested soils. Soil Sci. Soc. Am. J., 67: 1620-1628.

Purakayastha,T.J., Rudrapp, L., Singh, D., Swarup,A., Bhadraray,S. 2008. Longterm impact of fertilizers on soil organic carbon pools and sequestration rates in maize-wheat- cowpea cropping system. Geoderma, 144: 370-378.

Rudrappa, L., Purakayastha, T.J., Singh, D., Bhadraray, S. 2005. Long-term manuring and fertilization effects on soil organic carbon pools in a Typic Haplustept of semi-arid sub-tropical India. Soil Till. Res., 88:180-192.
Shah, Z., Shah, S.H., Peoples, M.B., Schwenke, G.D., Herriedge, D.F. 2003. Crop residue and fertilizer $\mathrm{N}$ effects on nitrogen fixation and yields of legume-cereal rotations and soil organic fertility. Field Crops Res., 83:1-11.

Shrestha, B.M., G. Certini., C. Forte and B. R. Singh. 2008. Soil organic matter quality under different land uses in a mountain watershed of Nepal. Soil Sci. Soc. Am. J. 72: $1563-1569$.

Sukkel, W., Geel, W., Van, J.J. 2008. Carbon sequestration in organic and conventional managed soils in the Netherlands. 16th IFOAM Organic World Congress, Modena, Italy.

Sundermeier, A., Randall, R., Lal, R. 2005. Soil Carbon Sequestration, Fundamentals of Food, Agricultural and Biological Engineering, 590, Woody Hayes Drive, Columbus, Ohio.

Venkatesh, M.S., Hazara, K.K., Ghosh, P.K., Prahara, C.S., Kumar, Narendra. 2013. Long-term effect of pulse and nutrient management on soil carbon sequestration in Indo-Gangetic plains of India. Can. J. Soil Sci., 93: 127-136.

Walkley, A.J. Black, I.A.1934. Estimation of Soil Organic Carbon by the chromic acid titration method. Soil Science, 37: 29-38.

Zhang, Q., Shamsi, I.H., Xu, D., Wang, G., Lin, X., Jilani, G., Hussain, N., Chaudhary, A.N. 2012. Chemical fertilizer and organic manure inputs in soil exhibit a vice versa pattern of microbial community structure. Appl. Soil Ecol., 57: $1-8$.

\section{How to cite this article:}

Parmar, D.K., and Thakur, D.R. 2017. Improvement in Soil Physical, Chemical and Microbiological Properties during Cropping Cycles under Different Nutrient Managements in Western Himalayas. Int.J.Curr.Microbiol.App.Sci. 6(6): 487-496. doi: https://doi.org/10.20546/ijcmas.2017.606.057 